\title{
A Study on Verbal Phrases in Tagulandang Dialect of Sangirese
}

\author{
1st Sarah Kamagi \\ English Language Department \\ Universitas Negeri manado \\ Manado, Indonesia \\ sarahkamagi@unima.ac.id
}

\author{
$2^{\text {nd }}$ Deane J. Wowor \\ English Language Department \\ Universitas Negeri manado \\ Manado, North Sulawesi \\ deanewowor@unima.ac.id
}

\author{
$3^{\text {rd }}$ Elisabeth Z. Oroh \\ English Language Department \\ Universitas Negeri manado \\ Manado, Indonesia \\ zuskaoroh@unima.ac.id
}

\author{
$4^{\text {th }}$ Rully Rantung \\ Fine Arts and Craft Department \\ Universitas Negeri manadoManado, \\ Indonesia \\ rullyrantung@unima.ac.id
}

\begin{abstract}
Verbal phrases in Tagulandang dialect of Sangirese, can be observed by two types of constructions namely endocentric and exocentric constructions. Endocentric construction: $i$ momo musamperi nakahengking daringihang, and balung kai malanighang mapia are verbal constructions in this local language bring about particular grammatical which need further analysis and discussion. This article, which is derived from a part of the results of a research entitled Aspek Linguistic dalam Pembuatan Londe Masyarakat Tradisional Sangir discusses the grammatical hirarchis of the tagmemes occure in the expressions used by Sangir people while they are making Londe. The main question as the basis of analysis and discussion presented in this paper is what are the types of construction used in Tagulandang dialect and the considerations that caused it to be called verbal. The analysis and discussion are to reveal and to explain the grammatical-structure of the constructions of the verbal phrases in this local language. The data and information presented in this paper were obtained through a library and linguistic field research. Nida's criteria is also used in selecting the informants to be choosen. The research conducted in the subdistrict of Northern part of Tagulandang namely Minanga village, in 2017. The data is descriptively analyzed based on relevant theories of linguistic, especially the grammatical- structure dealing with types of construction and the function, forms and position of its constituents in verbal constructions. Based on the result of analyzing data found that verbal in Tagulandang dialect consisted of two types of phrases namely endocentric contruction and exocentric construction. The verb in the construction can be accompanied by an adverb, or an adjective. The coordinative endocentric consists of the one using particle deng and that particle arako. The exocentric construction consists of that objective exocentric construction which indicates and act with direct object. In this construction the verb phrase followed by noun, preposition and noun, and functioned as subject, predicate, object and even complement as well.. It is hope that the description would provide more theories about linguistics as references for coming researcher who is interested in the related topic.
\end{abstract}

Keywords-construction, constituent, endocentric, exocentric, verbal, phrase

\section{INTRODUCTION}

Language has a function as a tool of communication used by human to express their thoughts, feelings, desires, and action. It constitutes a natural means of communication possessed by every human. About this function, Samsuri points out. "kemauan dan desakan untuk memakai salah satu bahasa tidak lain ialah keinginan manusia untuk mengadakan hubungan dengan manusia lain". It is basically asserts that the use of language is based on human need to communicate. According to Priestly (Alwasilah, 1993)[1], language is method of conveying ideas to the minds of other persons. This is supported also Webster (1983:726), who states, "language is a systematic means of communicating ideas of feeling by conventionalized sign, gestures, or marks, understood meaning". Based on the above definitions, it can be understood clearly that language constitutes a means of communication. It plays a very important role especially in getting and sharing information in the everyday life.

Due to this important role, researches on language are essential to be done for the sake of establishing and preserving language and culture. Similar attention is necessary to be paid on local languages. Considering the function and situation of local languages in connection with the national language of Indonesia (Bahasa Indonesia) and for the sake of preserving them as elements of Indonesian culture, local languages need to be preserved and be developed. It is for this reason that the goverment of Indonesia continuously motivates effort to preserve the local language. This is attention is stated in Guidelines of State Policy (GBHN 1993), which reads:

Bahasa daerah perlu dibina dan dilestarikan dalam rangka mengembangkan serta memperkaya perbendaharaan Bahasa Nasional sebagai salah satu unsur kepribadian bangsa. Dalam pada itu Bahasa daerah perlu terus dibina agar tetap mampu menjadi ungkapan budaya masyarakat yang mendukung ke-bhinekaan budaya sebagai unsur kreatifitas dan sumber kekuatan bangsa. Sejalan dengan itu 
perlu ditingkatkan penelitian, pengkajian, pengembangan Bahasa dan sastra.

This policy mainly point out that it is important for Indonesian people to preserve and develop the local languages in Indonesia.

Local languages are elements of culture. They share cultural values which only belong to Indonesian people that make it important to take care of the language. This is supported in the government's policy in the GBHN, specifically in the field of culture, which indicates that development of the Indonesian cultural values aims at strengthening the national unity. It is clear that the development of the local languages is not only the interest of the speakers of the languages, but also of the interest of the nation.

For the purpose mentioned above, effective investigations need to be conducted and increased. Through these investigation, data and information of the local languages can be used to develop language, linguistics, and literature and for the purpose of socio-cultural development. This can, at the same time, support the national development.

Sangirese is a local language found in North Sulawesi, out of more or less 583 local languages in Indonesia. It is language used by the people who live in Sangihe archipelago. It is used as tool of communication which has the same role and function to other languages in other region of Indonesia. It is should be preserved, so that it becomes a medium of communication among the speakers. This language is made up of several dialects. The dialects consist of Tabukan dialect, Manganitu dialect, Siau dialect, Tagulandang dialect, Kendahe dialect, Kolongan dialect and Tahuna dialect.

Sangirese is one of the four indigenous ethnic groups in North Sulawesi, Indonesia. Four big islands make up the archipelago where the language is spoken. They are : Sangir Besar, Siau, Tagulandang, and Biaro. Geographically, this archipelago lies between Sulawesi Island (Indonesia) and Mindanao (Philippines). This study is focused on the Tagulandang dialect of Sangirese which is a dialect of Sangirese used by the people who live in Tagulandang regency.

The researcher is interested to investigate the Tagulandang dialect and she focuses the investigation on verbal phrases which are used in sentences. This topic needs to be discussed as there is a lack of analytic descriptions on the topic. This research studies the problem of verbal phrases in the dialect. The topic of this study is chosen based on the consideration that Tagulandang dialect is beginning to extinct. This condition indicates that it is necessary to document the dialect for its establishment and preservation.

\section{RESEARCH METHODS}

The method used in the research was a descriptivequalitative which aimed at revealing and explaining the grammatical-structure of verbal phrase in Tagulandang dialect. The research was conducted in two forms namely field research and library research.. The field research was operationally conducted in the form of participatory- observation and depth interview with informants, and recording natural speech events as well. The library research was operationally conducted in the forms of documents analysis, selecting the relevant data, and note taking. The data are the verbal phrases of Tagulandang dialect which is consists of types of constructions, concerned with function, form and position of its constituents in the construction.

The source of data were the informants selected from the native speakers of Tagulandang dialect, taken from five informants who are from Minanga village that followed the criteria proposed by[2] :

1. They are native-speaker of Tagulandang dialect. It is intended to obtain utterances which are not much interfered by other language.

2. They are adult (40 to 70 years of age). It is considered that people who are in this age still speak the dialect actively.

3. They can either speak or understand the Bahasa Indonesia well. This is meant to have the informants able to transfer the Indonesian utterances in form of sentences in that local language.

4. They have good speaking ability. By this criteria, it is expected that utterances produced by the native speaker can be transcribed clearly.

5. They have good social relationship. Speakers of the dialect who have good social relationship are kind and also have good performance in the daily life.

The instrument used in collecting the data were researcher, quetioners, field notes sheets, recording equipment, and writing equipment. The analysis of data were based on relevant theories of linguistic syntactic, especially the theories of grammatical structure of verbal phrases. The result of analysis are descriptively presented in formal and informal ways as commonly used in linguistics.

\section{RESULT AND DISCUSSION}

The types of verbal phrases consist of endocentric construction and exocentric construction. It may cover of attributive endocentric construction function as similar to one of its direct element, where the verb can be accompanied by an adverb, or an adjective. Cordinative endocentric construction deng and arako as in muwalu deng muluang, musamperi arako manasa are commonly used in Tagulandang dialect in informal situation. Munasa kang, munasa su humping are verb phrase that could be followed either by noun or by preposition and noun indicating an act with direct object. The verb phrase manoso e function as subject in sentence manoso e makakoa taumata masaki, musalrai as object and natasae nuruang function as complement.

\section{CONCLUSION}

The types of verbal phrases consist of endocentric construction and exocentric construction. It may cover of attributive endocentric construction function as similar to one of its direct element, where the verb can be accompanied by an adverb, or an adjective. Cordinative endocentric construction deng and arako as in muwalu deng muluang, musamperi arako manasa are commonly used in Tagulandang dialect in informal situation. Munasa kang, munasa su humping are verb phrase that could be followed 
either by noun or by preposition and noun indicating an act with direct object. The verb phrase manoso e function as subject in sentence manoso e makakoa taumata masaki, musalrai as object and natasae nuruang function as complement. It is suggested that the analysis such as verbal construction are still highly needed in order to reveal the linguistics phenomena in a particular local language.

\section{ACKNOWLEDGMENT}

We would like to thank Lord Jesus for His kindness and grace that had enabled us to accomplish this research. We also would like to thank Alfret, Ramly and Etwin as native- speakers ot Sangirese for their help in collecting data. A major appreciation is expressed to LPPM UNIMA for allowing and supporting us by funding the research.

\section{REFERENCES}

[1] C. A. Alwasilah, Linguistik Suatu Pengantar. Bandung: Angkasa, 1993.

[2] E. A. Nida, "Morphology: The descriptive analysis of words.," 1949. 